\title{
DESCRIPTION OF A LITTLE-KNOWN RATTLESNAKE, CROTALUS WILLARDI, FROM ARIZONA.
}

\author{
By Frank A. Hartman, \\ Of the Queen Anne High School, Seattle, Washington.
}

About four years ago Dr. S. E. Meek described ${ }^{a}$ a new species of rattlesnake as Crotalus willardi from a single specimen collected at Tombstone, Arizona. During the University of Kansas Expedition of 1907 a second specimen of this distinct and interesting species
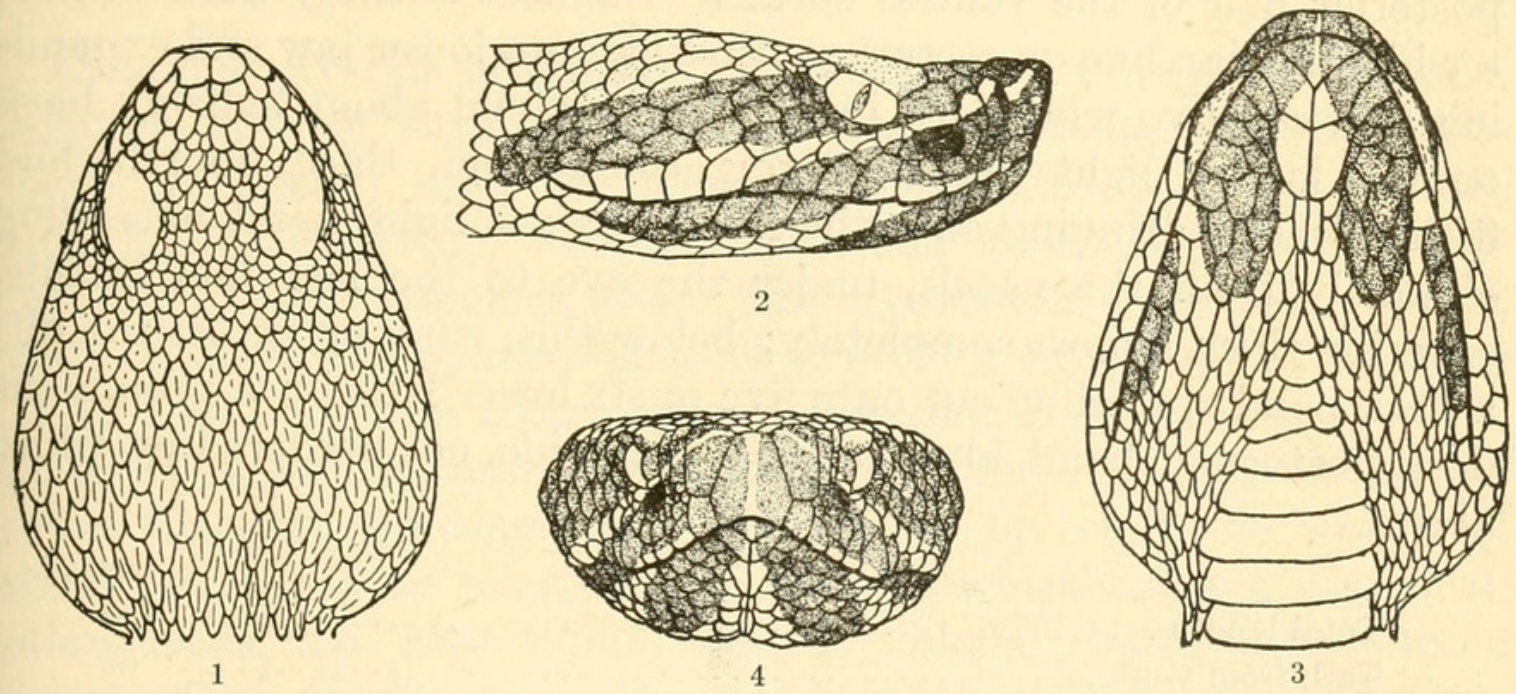

Figs. 1-4.-Crotalus willardi. $1 \frac{1}{2} \times$ NAT. SIze. 1 , TOP OF HEAD; 2 , SIDE OF HEAD; 3 , UNDERSIDE of HEAD; 4, HEAD FROM FRONT. No. 39896, U.S.N.M.

was collected in the region of the Santa Rita Mountain, Arizona, and has been donated to the United States National Museum.

In view of the rarity of the species it has been considered desirable to publish a somewhat detailed description of the latter specimen.

\section{CROTALUS WILLARDI Meek.}

Description.-Cat. No. 39896, U.S.N.M., Santa Rita Mountain, Arizona (figs. 1-4). Head long; muzzle narrow, somewhat recurved; rostral higher than wide; anterior nasal in contact with rostral; upper preocular not divided vertically; internasals as long as wide and turned up anteriorly into the canthus rostralis, which is very prominent; seven or eight scales in a line between supraoculars; two rows of scales between eye and supralabials; 14 supralabials on

$a$ Field Columb. Mus., Zool. Ser., vol. 7, No. 1, January, 1906, p. 18, pl. 3. 
left side, 13 on right; 13 lower labials on left side, 15 on right; 25 rows of scales, all keeled except first two, which are smooth; 153 ventrals; anal single; subcaudals 28 , first one and last three divided. General color chocolate (the specimen was changed from alcohol to formalin which caused the epidermis to peel off, leaving the snake of a grayish cast), dorsally marked with short crossbars of dark shading into a black line posteriorly or anteriorly, these bars sometimes occurring in pairs and then separated by one or two scales width of ground color; tail with three distinct brown half rings on anterior part, remainder uniform brown dorsally; brown spots covering parts or all of from one to four scales laterally; whole body more or less speckled with black or brown; lateral scales covered with fine specks; ventrals of anterior portion almost white, posteriorly becoming slightly speckled with dark, the specks farther back becoming so numerous as to merge into spots or blotches until the posterior half of the ventral surface is almost entirely dark brown; a white median line on rostral continuing onto lower jaw and expanding between two wide dark bars, which extend about halfway back on the jaw; a light line bordering the second, third, fourth, and fifth labials continuing onto the lower jaw; a light band extending obliquely from the nasals, under the eye to the last four labials, covering them almost completely; below this, running across the pit, a dark band spreading out onto five or six lower labials; a prominent dark postocular band, about three scales wide, not bordered by white above.

Dimensions.

$m m$.

Total length . . . . . . . . . . . . . . . . . . . . . . . . . . . . 495

Tail, from vent...................................... 51

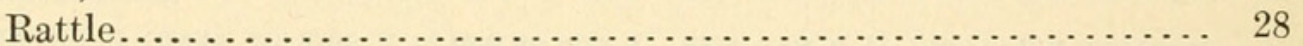

Remarks.-This specimen shows but few differences from Doctor Meek's brief description of the type. The latter, which has a body length of $380 \mathrm{~mm}$. and a tail of $35 \mathrm{~mm}$., has 160 ventrals and 24 subcaudals, and Doctor Meek describes its color as "light olivebrown, more or less irregularly blotched with white."

Doctor Meek says: "In general, this species bears some resemblance to Crotalus lepidus Kennicott. It differs in being light brown instead of greenish gray, and in having shorter transverse dorsal bars, which are much lighter than the ground color, instead of black crossbars, which are so characteristic of $C$.lepidus." I have made a careful study of Crotalus willardi and can find no resemblance to C. lepidus. The snout is elevated and not depressed, the head is triangular instead of oval; dorsal scale rows 25 instead of 23 ; the ground color is brown instead of greenish gray; there are no stripes on the side of the head of $C$. lepidus. In fact, instead of resemblances there seems to be considerable contrast between the two species. 


\section{$2 \mathrm{BHL}$ Biodiversity Heritage Library}

Hartman, Frank Alexander. 1911. "Description of a little-known rattlesnake, Crotalus willardi, from Arizona." Proceedings of the United States National Museum 39(1800), 569-570. https://doi.org/10.5479/si.00963801.39-1800.569.

View This Item Online: https://www.biodiversitylibrary.org/item/53443

DOI: https://doi.org/10.5479/si.00963801.39-1800.569

Permalink: https://www.biodiversitylibrary.org/partpdf/51992

\section{Holding Institution}

Smithsonian Libraries

\section{Sponsored by}

Smithsonian

\section{Copyright \& Reuse}

Copyright Status: Public domain. The BHL considers that this work is no longer under copyright protection.

This document was created from content at the Biodiversity Heritage Library, the world's largest open access digital library for biodiversity literature and archives. Visit BHL at https://www.biodiversitylibrary.org. 